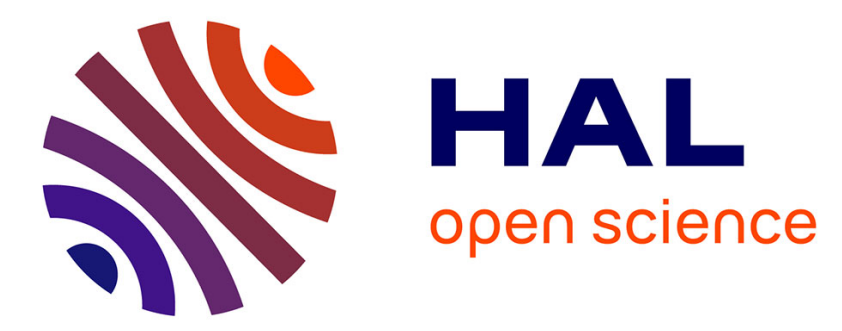

\title{
Pseudopulchellol: A unique sesquiterpene-monoterpene derived C-25 terpenoid from the leaves of Croton pseudopulchellus Pax (Euphorbiaceae)
}

Moses K Langat, Neil R Crouch, Jean-Marc Nuzillard, Dulcie A Mulholland

\section{- To cite this version:}

Moses K Langat, Neil R Crouch, Jean-Marc Nuzillard, Dulcie A Mulholland. Pseudopulchellol: A unique sesquiterpene-monoterpene derived C-25 terpenoid from the leaves of Croton pseudopulchellus Pax (Euphorbiaceae). Phytochemistry Letters, 2018, 23, pp.38 - 40. 10.1016/j.phytol.2017.11.008 . hal-01692488

\section{HAL Id: hal-01692488 \\ https://hal.science/hal-01692488}

Submitted on 10 Sep 2021

HAL is a multi-disciplinary open access archive for the deposit and dissemination of scientific research documents, whether they are published or not. The documents may come from teaching and research institutions in France or abroad, or from public or private research centers.
L'archive ouverte pluridisciplinaire $\mathbf{H A L}$, est destinée au dépôt et à la diffusion de documents scientifiques de niveau recherche, publiés ou non, émanant des établissements d'enseignement et de recherche français ou étrangers, des laboratoires publics ou privés. 


\section{Pseudopulchellol: a Unique Sesquiterpene-Monoterpene Derived C-25 Terpenoid from the Leaves of Croton pseudopulchellus Pax (Euphorbiaceae)}

Moses K. Langat, ${ }^{\mathrm{a}, \mathrm{b}, *}$ Neil R. Crouch, ${ }^{\mathrm{b}, \mathrm{c}}$ Jean-Marc Nuzillard ${ }^{\mathrm{d}}$ and Dulcie A. Mulholland ${ }^{\mathrm{a}, \mathrm{b}}$

${ }^{a}$ Natural Products Research Group, Department of Chemistry, Faculty of Engineering and Physical Sciences, University of Surrey, Guildford GU2 7XH, UK

${ }^{\mathrm{b}}$ School of Chemistry and Physics, University of KwaZulu-Natal, Durban 4041, South Africa

${ }^{\mathrm{c}}$ Biodiversity Research, Monitoring and Assessment, South African National Biodiversity Institute, PO Box 52099, Berea Road, 34007, Durban, South Africa

d Institut de Chimie Moléculaire de Reims, UMR CNRS 7312, SFR Cap'Sante, Université de Reims-Champagne-Ardenne, France

\section{Corresponding Author}

* Tel: +44 (0) 148368 9580. E-mail: m.langat@surrey.ac.uk

\section{Keywords:}

Pseudopulchellol, sesquiterpene-monoterpene, Croton pseudopulchellus, electronic circular dichroism 


\begin{abstract}
A C-25 terpenoid, pseudopulchellol, a rare example of a compound formed by the combination of a monoterpenoid and a sesquiterpenoid unit, was isolated along with eudesm-4(15)-en-1 $\beta, 6 \alpha$-diol, its likely precursor, and nine known compounds, including six ent-kaurenoic acids, from the leaves of Croton pseudopulchellus. ECD studies were used to assign the absolute configuration of pseudopulchellol.
\end{abstract}




\section{Introduction}

Croton pseudopulchellus Pax (Euphorbiaceae) is a shrub endemic to Africa, widely distributed in tropical East, West and southern Africa (Burkill, 1994; Schmidt et al., 2002). The olive green leaves of C. pseudopulchellus are small, and the underside is silvery and densely dotted with orange scales. In East Africa the leaves are applied directly to treat chest infections (Burkill, 1994), or taken internally as infusions or decoctions to treat syphylitic ulcers (Bally, 1937), gonorrhoea, colds, and anthrax (Kokwaro, 1976). The leaves, which have a pleasant aromatic smell when crushed, are burnt between crops for their insecticidal properties (Kokwaro, 1976). In West Africa (Ghana) these organs are employed as antitussives and antivirals (Irvine, 1961). We previously reported that the stem bark of C. pseudopulchellus contains ent-14S-hydroxykaur-16-en-19-oic acid, ent-14S,17-dihydroxykaur-15-en-19-oic acid, ent-kaur-16-en-19-oic acid, ent-kaur-16-en-

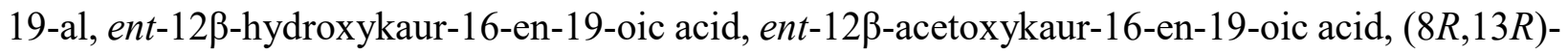

epoxylabd-14-ene, eudesm-4(15)-ene-1 $\beta, 6 \alpha$-diol, $\quad(-)$-7-epivaleran-4-one, germacra4(15),(5E),10(14)-trien-9 $\beta$-ol, acetyl aleuritolic acid, $\beta$-amyrin, and stigmasterol, and tested the activity of the kaurenoic acids against Semliki virus replication (Langat et al., 2012). The leaves of $C$. pseudopulchellus were investigated in this study.

\section{Results and discussion}

A new C-25 terpenoid alcohol, derived from the combination of a sesquiterpene and a monoterpene, named pseudopulchellol (1) (Fig. 1), its likely precursor, eudesm-4(15)-en-1 $\beta, 6 \alpha-$ diol (2) (Sun et al., 2004), six known ent-kaur-16-en-19-oic acid derivatives, ent-kaur-16-en-19oic acid (Vieira et al., 2002), ent-kaur-16-en-19-al (Piozzi, et al., 2002), ent-12ß-hydroxykaur-16en-19-oic acid (Ortega et al., 1985), ent-12ß-acetoxykaur-16-en-19-oic acid (Bohlmann et al., 1980), ent-(14S)-hydroxykaur-16-en-19-oic acid (Langat et al., 2012), ent-15ß-hydroxykaur-16- 
en-19-oic acid (Piozzi et al., 1968), in addition to (8R,13R)-epoxylabd-14-ene (Zhou et al., 1995), $\beta$-amyrin and stigmasterol, were isolated from the combined hexane and dichloromethane extracts of the leaves of Croton pseudopulchellus.

HR-ESIMS data of pseudopulchellol (1) showed a $\mathrm{M}^{+}$ion at $\mathrm{m} / \mathrm{z}$ 356.3181, indicating a molecular formula of $\mathrm{C}_{25} \mathrm{H}_{40} \mathrm{O}$. The IR spectrum showed peaks at $3401(\mathrm{OH}$-stretch) and 1658 $\mathrm{cm}^{-1}(\mathrm{C}=\mathrm{C}$ double bond stretch). The NMR spectra showed similarities to the co-isolated eudesm4(15)-en-1 $\beta, 6 \alpha$-diol, but were more complex and the mass spectrum indicated an additional ten carbon atoms. A monoacetate was obtained on acetylation of $\mathbf{1}$. The Logic for Structure Determination (LSD) protocol (Nuzillard, 2003; Nuzillard, 2015) was used to determine that pseudopelchellol (1) consisted of the sesquiterpene, eudesm-4(15)-ene- $6 \alpha$-ol, attached at the C-1 $\beta$ position to $\mathrm{C} 10$ of the monoterpene, $\alpha$-pinene. The LSD input file for pseudopelchellol (1) is provided as Supporting Information. The file contains a description of all non-hydrogen atoms (chemical element, hybridization state, number of attached hydrogen atoms) and lists of HSQC, COSY and HMBC correlations.

The ${ }^{13} \mathrm{C}$ NMR spectrum showed the presence of twenty-five carbon resonances including resonances ascribed to two double bonds $\left(\delta_{\mathrm{C}} 148.7, \mathrm{C}-4 ; \delta_{\mathrm{C}} 106.2, \mathrm{C}-15 ; \delta_{\mathrm{C}} 147.1, \mathrm{C}-1{ }^{\prime} ; \delta_{\mathrm{C}} 117.8\right.$, C-2'). For the eudesm-4(15)-ene-6 $\alpha$-ol part of the structure, the COSY spectrum showed the following coupled sequences: $\mathrm{H}_{3}-12$ and $\mathrm{H}_{3}-13\left(\delta_{\mathrm{H}} 0.94, \delta_{\mathrm{H}} 0.86\right) / \mathrm{H}-11\left(\delta_{\mathrm{H}} 2.24\right), \mathrm{H}-11 / \mathrm{H}-7\left(\delta_{\mathrm{H}}\right.$ $1.30), \mathrm{H}-7 / \mathrm{H}-6\left(\delta_{\mathrm{H}} 3.70\right), \mathrm{H}-6 / \mathrm{H}-5\left(\delta_{\mathrm{H}} 1.81\right), \mathrm{H}-7$ / two H-8 $\left(\delta_{\mathrm{H}} 1.50, \delta_{\mathrm{H}} 1.20\right)$, two H-8 / two $\mathrm{H}-9\left(\delta_{\mathrm{H}} 1.85, \delta_{\mathrm{H}} 1.09\right)$ and H-1 $\left(\delta_{\mathrm{H}} 1.29\right) /$ two H-2 $\left(\delta_{\mathrm{H}} 1.76, \delta_{\mathrm{H}} 1.16\right) /$ two H-3 $\left(\delta_{\mathrm{H}} 2.30, \delta_{\mathrm{H}} 1.95\right)$. Correlations were seen in the HMBC spectrum between the $\mathrm{H}_{3}-14\left(\delta_{\mathrm{H}} 0.60\right)$ resonance and the $\mathrm{C}$ $10\left(\delta_{\mathrm{C}} 40.5\right)$ and $\mathrm{C}-5\left(\delta_{\mathrm{C}} 59.6\right)$ resonances and the exomethylene $2 \mathrm{H}-15\left(\delta_{\mathrm{H}} 4.96, \delta_{\mathrm{H}} 4.65\right)$ resonances and the $\mathrm{C}-3\left(\delta_{\mathrm{C}} 37.9\right), \mathrm{C}-4\left(\delta_{\mathrm{C}} 148.7\right)$ and $\mathrm{C}-5\left(\delta_{\mathrm{C}} 59.6\right)$ resonances. 
For the $\alpha$-pinene part, the $\mathrm{H}_{3}-8$ ' (1.27 ppm) and $\mathrm{H}_{3}-9^{\prime}(0.83 \mathrm{ppm})$ resonances showed correlations in the HMBC spectrum with the C-7' (38.4 ppm), C-6' (45.7 ppm) and C-4' (41.1 ppm) resonances. The COSY spectrum showed the following coupled sequence: H-6' (1.98 ppm) / two H-5' (2.38 ppm and 1.10 ppm), two H-5' / H-4' (2.08 ppm), H-4' / two H-3' (2.24 ppm and $2.18 \mathrm{ppm})$ and $\mathrm{H}-3$ ' to the H-2' alkene proton resonance (5.13 ppm). The COSY spectrum showed coupling between the $\mathrm{H}-1$ and the non-equivalent $\mathrm{H}-10$ ' methylene proton resonances $(2.07 \mathrm{ppm}$ and $1.51 \mathrm{ppm})$. The two H-10' proton resonances showed correlations in the HMBC experiment with C-1, C-2, C-1' (147.1 ppm), C-2' (117.8 ppm) and C-6' (45.7 ppm) resonances, confirming that eudesm-4(15)-en-6 $\alpha$-ol was bonded to the $\alpha$-pinene unit via $\mathrm{C}-1$ and $\mathrm{C}-10$ '.

The NOESY spectrum showed correlations between the isopropyl group proton resonances $(\mathrm{H}-$ 11, H-12 and H-13) and H-6, H-6 and H-14, H-14 and one of the H-10 resonances, indicating that the isopropyl group, H-6, H-14 and the $\alpha$-pinene unit were on the same face of the molecule, and between the H-1 (1.29 ppm) and/or H-7 (1.30 ppm) and the H-5 resonance indicating that H-1/H7 and H-5 were on the other face of the molecule. These showed that the relative configuration for the eudesmane sesquiterpenoid part of pseudopulchellol was the same as for eudesm-4(15)-en-6 $\alpha$ ol ( $\beta$-verbesinol) (Gardner et al., 1961) and eudesm-4(15)-ene-1 $\beta, 6 \alpha$-diol (Sun et al., 2004) also isolated in this study. The absolute configuration of eudesm-4(15)-ene-1 $\beta, 6 \alpha$-diol has been determined $^{7}$ and the specific rotation of eudesm-4(15)-ene-1 $\beta, 6 \alpha$-diol (2) isolated in this work (+ $44^{\circ}$ ) matched the literature value $\left(+45^{\circ}\right)$ (Sun et al., 2004). This was supported by the NOESY spectrum showing correlations between the H-4' and H-6' but not between the H-5' and H-8' and H-9' resonances.

Electronic circular dichroism (ECD) studies were used to determine the absolute configuration of pseudopulchellol. The ECD data for pseudopulchellol, eudesm-4(15)-ene-1 $\beta, 6 \alpha$-diol, (-)-pinene 
and (+)-pinene were obtained. The ECD contribution by eudesm-4(15)-ene-1 $\beta, 6 \alpha$-diol whose absolute configuration is known (Sun et al., 2004) was subtracted from the ECD data of pseudopulchellol, allowing for the contribution of the pinene group to be determined, and the resulting ECD curve was compared to the ECD curves for (-)-pinene and (+)-pinene. It was observed that the contributing ECD effect in pseudopulchellol was due to (+)-pinene (Fig. 2). In addition, two structures of pseudopulchellol including the (+)-pinene (1) and (-)-pinene (1a) moieties were modelled following the protocol we have reported previously (Langat et al., 2014; Tembu et al., 2015) and their simulated ECD curves (Frisch et al., 2010) were compared to the experimental data for pseudopulchellol (Fig. 3) and this confirmed that the (+)-pinene moiety was a constituent of pseudopulchellol. The specific rotation for pseudopulchellol was determined as + $35^{\circ}$ whereas the specific rotation reported for the eudesmane sesquiterpenoid, eudesm-4(15)-ene$1 \beta, 6 \alpha$-diol was $+45^{\circ}$ and that of $(+)$-pinene is $+42^{\circ}$.

The formation of the $\mathrm{C}-1$ / C-10' bond could occur by the eudesmane part losing the 1-hydroxy group to generate a carbocation that reacts with the $\mathrm{C}-1^{\prime}\left(10^{\prime}\right)$-double bond of $\beta$-pinene with loss of a H-2' proton to generate the C-1'double bond.

\section{Experimental section}

\subsection{General experimental procedures}

Optical rotations were measured at room temperature on a JASCO-P-1020 polarimeter and IR spectra were recorded using a Perkin-Elmer (2000 FTIR) spectrophotometer using KBr windows. ECD spectra were measured on an Applied Photophysics Chirsascan CD spectrometer using a 1 mm cell and $\mathrm{CHCN}$ as the solvent. ${ }^{1} \mathrm{H},{ }^{13} \mathrm{C}$ and 2D NMR spectra were recorded on a Bruker AVANCE III NMR spectrometer, operating at $500 \mathrm{MHz}$ for ${ }^{1} \mathrm{H}$ and $125 \mathrm{MHz}$ for ${ }^{13} \mathrm{C}$, using standard experiments from the Bruker pulse programs library. Chemical shifts are reported in ppm ( $\delta$ ) referencing the solvent signal $\left(\mathrm{CDCl}_{3}\right)$ as internal standard respect to TMS (0 ppm), and 
coupling constants $(J)$ are measured in Hz. HREIMS was performed on a Bruker MicroToF Mass Spectrometer, using an Agilent 1100 HPLC to introduce samples. Gravity column chromatography was performed using silica gel (Merck Art. 9385) packed 1 or $4 \mathrm{~cm}$ diameter columns. TLC was performed on aluminium precoated silica gel plates (Merck 9385) visualised using anisaldehyde spray reagent.

\subsection{Plant material}

Leaves from C. pseudopulchellus Pax, cultivated on the University of KwaZulu-Natal campus, Durban, South Africa, were collected in August 2005 and a fertile voucher retained at the KwaZulu-Natal Herbarium for verification purposes (Crouch 1050, NH).

\subsection{Extraction and isolation}

Air dried, powdered leaves of $C$. pseudopulchellus $(1.6 \mathrm{~kg})$ were extracted in a Soxhlet apparatus using $n$-hexane, $\mathrm{CH}_{2} \mathrm{Cl}_{2}$, EtOAc and $\mathrm{MeOH}$ successively to give 18.5, 10.2, 2.5 and 91.0 g of extract respectively. The $n$-hexane and $\mathrm{CH}_{2} \mathrm{Cl}_{2}$ extracts were combined due to similarities on TLC and separated using column chromatography over silica gel (Merck 9385). A detailed separation scheme is provided in the supporting information.

\subsection{Computational methods}

The conformational search was carried out for (1) and (1a) at the molecular mechanics level of theory employing the MMFF force field basis set incorporated in the Spartan8 (Wavefunction, Irvine, CA) software package. Conformers under $2 \mathrm{kcal} / \mathrm{mol}$ were selected for time dependent density functional theory (TDDFT) calculations. The selected conformers were subjected to time dependent density functional theory (TDDFT) calculations using a B3LYP method built into Gaussian09 software at a 6-31G (d,f) level using the "Self-Consistent Reaction Field" method (SCRF) with conductor-like polarizable continuum model (CPCM) model in acetonitrile for 20 
electronic excitation states (Frisch et al., 2010). The ECD curves were Boltzmann weighted and compared.

\section{Compound characterization}

Pseudopulchellol (1): colourless oil; $[\alpha]^{25}{ }_{\mathrm{D}}+35\left(c 0.0350, \mathrm{CHCl}_{3}\right) ; \mathrm{ECD} c 0.0003,0.1 \mathrm{~cm}$ path length, ACN): $196 \mathrm{~nm}(\Delta \varepsilon-2.5), 214 \mathrm{~nm}(\Delta \varepsilon+2.0), 220 \mathrm{~nm}(\Delta \varepsilon+2.4)$; IR (neat on $\mathrm{KBr}$ windows) $v_{\max } 3401,2927,2868,1658 \mathrm{~cm}^{-1} ;{ }^{1} \mathrm{H} \mathrm{NMR}\left(\mathrm{CDCl}_{3}, 500 \mathrm{MHz}\right)$ and ${ }^{13} \mathrm{C} \mathrm{NMR}\left(\mathrm{CDCl}_{3}, 125 \mathrm{MHz}\right)$ data are given in Table 1; HR-ESIMS $m / z$ 356.3181 [M] $]^{+}$(calcd for $\mathrm{C}_{25} \mathrm{H}_{40} \mathrm{O}, 356.3080$ ).

\section{Acknowledgment}

ML acknowledges a Ph.D. studentship from the University of Surrey and the South African National Research Foundation (NRF) for funding this project. The authors thank Colin Sparrow of the University of Oxford for MS analyses.

\section{Appendix A. Supplementary data}

The supplementary data associated with this article can be found in the online version, at http://dx.doi.orh/xxxx/j.phytol.201y.xx.xxx 


\section{References}

Bally, P.R.O. 1937. II.-Native medicinal and poisonous plants of East Africa. Kew Bulletin, $1,10-26$.

Bohlmann, F., Knoll, K.H., Robinson, H., King, R.M. 1980. Neue kauren-derivative und melampolide aus Smallanthus uvedalia. Phytochemistry, 19, 107-110.

Burkill, H.M. 1994. The Useful Plants of West Tropical Africa, vol. 2. Families E-I, Royal Botanic Gardens, Kew, pp. 49.

Frisch, M.J.T., Trucks, G,W., Schlegel, H.B., Scuseria, G.E., Robb, M.A., Cheeseman, J.R., Scalmani, G., Barone, V., Mennucci, B. Petersson, G.A., Nakatsuji, H., Caricato, M., Li, X., Hratchian, H.P., Izmaylov, A.F., Bloino, J., Zheng, G., Sonnenberg, J.L., Hada, M., Ehara, M., Toyota, K., Fukuda, R., Hasegawa, J., Ishida, M., Nakajima,T., Honda, Y., Kitao, O., Nakai, H., Vreven, T., Montgomery, J.A., Jr., Peralta, J.E., Ogliaro, F., Bearpark, M., Heyd, J.J., Brothers, E., Kudin, K.N., Staroverov, V.N., Kobayashi, R., Normand, J., Raghavachari, K., Rendell, A., Burant, J.C., Iyengar, S.S., Tomasi, J., Cossi, M., Rega, N., Millam, N.J., Klene, M., Knox, J.E., Cross, J.B., Bakken, V., Adamo, C., Jaramillo, J., Gomperts, R., Stratmann, R. E., Yazyev, O., Austin, A.J., Cammi, R., Pomelli, C., Ochterski, J.W., Martin, R.L., Morokuma, K., Zakrzewski, V.G., Voth, G.A., Salvador, P., Dannenberg, J.J., Dapprich, S., Daniels, A.D., Farkas, Ö., Foresman, J.B., Ortiz, J.V., Cioslowski, J., Fox, D.J. 2009. Gaussian09, Revision B.01; Gaussian, Inc.: Wallingford, CT.

Gardner, P.D., Park, G.J., Albers, C.C. 1961. $\alpha$ - and $\beta$-verbesinol sesquiterpene alcohols of the cis-decalin series. J. Am. Chem. Soc., 83, 1511-1512.

Irvine, F.R. 1961. Woody Plants of Ghana. Oxford University Press, London, pp. 878. 
Kokwaro, J.O. 1976. Medicinal Plants of East Africa. East African Literature Bureau, Nairobi, pp. 89.

Langat, M.K., Crouch, N.R., Pohjala, L., Tammela, P., Smith, P.J., Mulholland, D.A. 2012. Ent-kauren-19-oic acid derivatives from the stem bark of Croton pseudopulchellus Pax. Phytochem. Lett., 5, 414-418.

Langat, M.K., Randrianavelojosia, M., Langat, L.C., Plant, N., Mulholland, D.A. 2014. Langaside, a novel secoiridolactone glycoside deriviative from Tachiadenus longiflorus Griseb. (Gentianaceae) formed by a [2+2] cycloaddition reaction. Phytochem. Lett., 10, cxviii - cxxii.

Nuzillard, J.-M. 2003. Automatic structure determination of organic molecules: principles and implementation of the LSD program. Chin. J. Chem., 21, 1263-1267.

Nuzillard, J.-M. 2015. Logic for Structure Determination software, version 3.4.9. Reins, France, 2015. Available from: http://www.univ-reims.fr/LSD (Accessed June 2015).

Ortega, A., Morales, F.J., Salmon, M. 1985. Kaurenic acid derivatives from Stevia eupatoria. Phytochemistry, 24, 1850-1852.

Piozzi, F., Passannanti, S., Paternostro, M. 1971. Kauranoid diterpenes in Espeletia grandiflora. Phytochemistry, 10, 1164-1166.

Piozzi, E., Sprio, V., Passannanti, R., Mondelli, R. 1968. Structura dell'acido grandiflorolico. Gazz. Chim. Ital., 98, 907-910.

Schmidt, E., Lotter, M., McCleland, W. 2002. Trees and Shrubs of Mpumalanga and Kruger National Park, Jacana, Johannesburg, pp. 274.

Sun, Z., Chen, B., Zhang, S., Hu, C. 2004. Four new eudesmanes from Caragana intermedia and their biological activities. J. Nat. Prod., 67, 1975-1979. 
Tembu, V.J., Langat, M.K., Crouch, N.R., Mulholland, D.A. 2015. Use of circular dichroism to determine the absolute configuration of a pimarane diterpenoid from the southern African Sclerocroton integerrimus (Euphorbiaceae). Nat. Prod. Comm., 9, 1131-1133.

Vieira, H.S., Takahashi, J.A., de Oliveira, A.B., Chiari, E., Boaventura, M.A.D. 2002. Novel derivatives of kaurenoic acid: Preparation and evaluation of their trypanocidal activity. J. Braz. Chem. Soc., 13, 151-157.

Zhou, L., Fuentes, E.R., Hoffmann, J.J., Timmermann, B.N. 1995. Diterpenoids from Grindelia tarapacana. Phytochemistry, 40, 1201-1207. 


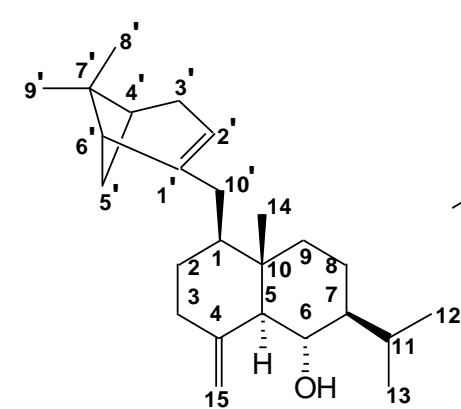

1

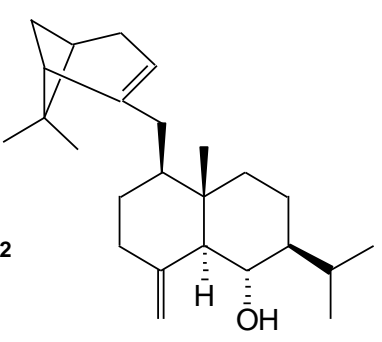

$1 a$

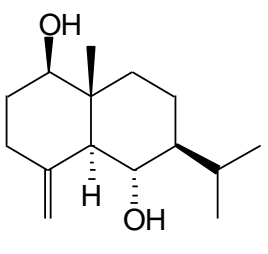

2

Figure 1. Structures of compounds 1,1 a and 2

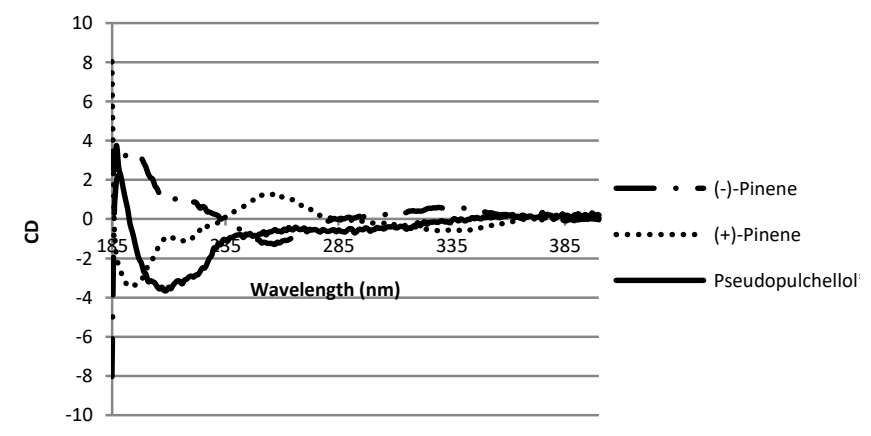

Figure 2. Experimental ECD spectrum of pseudopulchellol after subtracting the effect of eudesm-4(15)-ene-1ß,6 $\alpha$-diol and compared with the experimental ECD spectra of $(+)$-pinene and (-)-pinene.

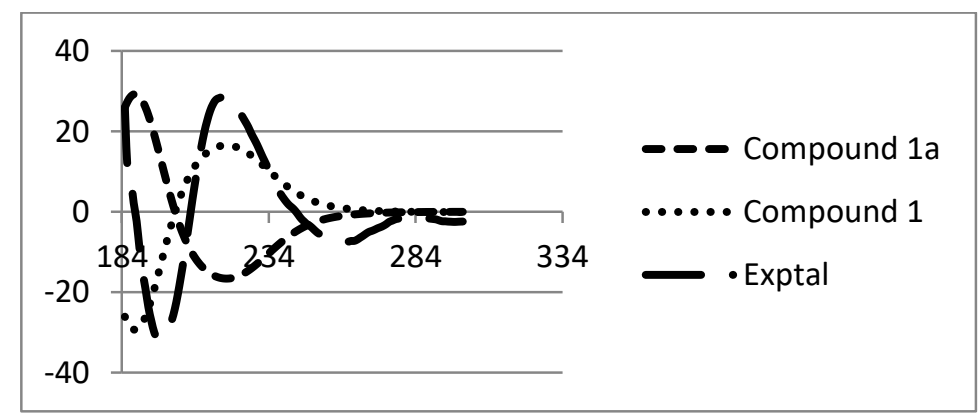

Figure 3: Experimental ECD spectrum for compound 1 and TDDFT simulated spectra for 1 and 1a. Units for the $y$-axis are $(\Delta \varepsilon)$ and $\lambda(\mathrm{nm})$ for the $\mathrm{x}$-axis. 
Table 1. ${ }^{1} \mathrm{H}$ and ${ }^{13} \mathrm{C}$ NMR data for pseudopulchellol (1), eudesm-4(15)-ene-1ß,6 $\alpha$-diol (2) and $\alpha$-pinene

\begin{tabular}{|c|c|c|c|c|c|c|}
\hline & \multicolumn{3}{|c|}{${ }^{13} \mathrm{C}$ NMR (125 MHz, $\left.\mathrm{CDCl}_{3}\right)$} & \multicolumn{3}{|c|}{${ }^{1} \mathrm{H}_{\mathrm{NMR}}\left(\mathrm{MHz}, \mathrm{CDCl}_{3}\right)$} \\
\hline No. & 1 & 2 & $\alpha$-pinene & 1 & $\mathbf{2}$ & $\alpha$-pinene \\
\hline 1 & $46.2 \mathrm{CH}$ & $79.2 \mathrm{CH}$ & & $1.29 \mathrm{~m}$ & $3.42 \mathrm{dd} J=11.6,4.7 \mathrm{~Hz}$ & \\
\hline $2 \alpha$ & $30.2 \mathrm{CH}_{2}$ & $32.1 \mathrm{CH}_{2}$ & & $1.76 \mathrm{~m}$ & $1.85 \mathrm{~m}$ & \\
\hline $2 \beta$ & & & & $1.16 \mathrm{~m}$ & $1.53 \mathrm{~m}$ & \\
\hline $3 \alpha$ & $37.9 \mathrm{CH}_{2}$ & $35.3 \mathrm{CH}_{2}$ & & $1.95 \mathrm{~m}$ & $2.05 \mathrm{~m}$ & \\
\hline $3 \beta$ & & & & $2.30 \mathrm{~m}$ & $2.34 \mathrm{~m}$ & \\
\hline 4 & $148.7 \mathrm{C}$ & $146.5 \mathrm{C}$ & & - & - & \\
\hline $5 \alpha$ & $59.6 \mathrm{CH}$ & $56.1 \mathrm{CH}$ & & $1.81 \mathrm{~d} J=9.5 \mathrm{~Hz}$ & $1.75 \mathrm{~d} J=9.8 \mathrm{~Hz}$ & \\
\hline $6 \beta$ & $67.3 \mathrm{CH}$ & $67.2 \mathrm{CH}$ & & $3.70 \mathrm{t} J=9.5 \mathrm{~Hz}$ & $3.72 \mathrm{t} J=9.8 \mathrm{~Hz}$ & \\
\hline $7 \alpha$ & $49.5 \mathrm{CH}$ & $49.5 \mathrm{CH}$ & & $1.30 \mathrm{~m}$ & $1.29 \mathrm{~m}$ & \\
\hline $8 \alpha$ & $18.6 \mathrm{CH}_{2}$ & $18.4 \mathrm{CH}_{2}$ & & $1.50 \mathrm{~m}$ & $1.25 \mathrm{~m}$ & \\
\hline $8 \beta$ & & & & $1.20 \mathrm{~m}$ & $1.60 \mathrm{~m}$ & \\
\hline $9 \alpha$ & $37.9 \mathrm{CH}_{2}$ & $36.5 \mathrm{CH}_{2}$ & & $1.09 \mathrm{~m}$ & $1.19 \mathrm{~m}$ & \\
\hline $9 \beta$ & & & & $1.85 \mathrm{~m}$ & $1.90 \mathrm{~m}$ & \\
\hline 10 & $40.5 \mathrm{C}$ & $42.0 \mathrm{C}$ & & - & - & \\
\hline $11 \alpha$ & $26.3 \mathrm{CH}$ & $26.2 \mathrm{CH}$ & & $2.24 \mathrm{~m}^{*}$ & $2.24 \mathrm{~m}$ & \\
\hline $12 \beta$ & $16.4 \mathrm{CH}_{3}$ & $16.4 \mathrm{CH}_{3}$ & & $0.86 \mathrm{~d} J=7.0 \mathrm{~Hz}$ & $0.87 \mathrm{~d} J=7.1 \mathrm{~Hz}$ & \\
\hline $13 \alpha$ & $21.3 \mathrm{CH}_{3}$ & $21.3 \mathrm{CH}_{3}$ & & $0.94 \mathrm{~d} J=7.5 \mathrm{~Hz}$ & $0.95 \mathrm{~d} J=7.1 \mathrm{~Hz}$ & \\
\hline 14 & $13.4 \mathrm{CH}_{3}$ & $11.8 \mathrm{CH}_{3}$ & & $0.60 \mathrm{~s}$ & $0.71 \mathrm{~s}$ & \\
\hline $15 \mathrm{~A}$ & $106.2 \mathrm{CH}_{2}$ & $108.0 \mathrm{CH}_{2}$ & & 4.65 br s & $4.75 \mathrm{~s}$ & \\
\hline $15 B$ & & & & 4.96 br s & $5.02 \mathrm{~s}$ & \\
\hline $1 '$ & $147.1 \mathrm{C}$ & & $144.5 \mathrm{C}$ & & & \\
\hline $2{ }^{\prime}$ & $117.8 \mathrm{CH}$ & & $116.0 \mathrm{CH}$ & 5.13 br s & & 5.19 br s \\
\hline $3^{\prime} \alpha$ & $31.6 \mathrm{CH}_{2}$ & & $31.3 \mathrm{CH}_{2}$ & $2.24 \mathrm{~m}^{*}$ & & $2.23 \mathrm{~m}$ \\
\hline $3^{\prime} \beta$ & & & & $2.18 \mathrm{~m}$ & & $2.16 \mathrm{~m}$ \\
\hline 4' & $41.1 \mathrm{CH}$ & & $40.7 \mathrm{CH}$ & $2.08 \mathrm{~m}$ & & $2.07 \mathrm{~m}$ \\
\hline $5^{\prime} \alpha$ & $32.1 \mathrm{CH}_{2}$ & & $38.0 \mathrm{CH}_{2}$ & $2.38 \mathrm{~m}$ & & $2.33 \mathrm{~m}$ \\
\hline $5^{\prime} \beta$ & & & & $1.10 \mathrm{~m}$ & & $1.15 \mathrm{~m}$ \\
\hline 6 & $45.7 \mathrm{CH}$ & & $47.0 \mathrm{CH}$ & 1.98 & & $1.93 \mathrm{~m}$ \\
\hline 7 & $38.4 \mathrm{C}$ & & $31.5 \mathrm{C}$ & - & & - \\
\hline 8 ' & $26.6 \mathrm{CH}_{3}$ & & $26.4 \mathrm{CH}_{3}$ & $1.27 \mathrm{~s}$ & & $1.26 \mathrm{~s}$ \\
\hline 9’ & $21.1 \mathrm{CH}_{3}$ & & $20.8 \mathrm{CH}_{3}$ & $0.83 \mathrm{~s}$ & & $0.83 \mathrm{~s}$ \\
\hline $10^{\prime} \alpha$ & $37.8 \mathrm{CH}_{2}$ & & $23.1 \mathrm{CH}_{3}$ & $2.07 \mathrm{~m}$ & & $1.66 \mathrm{~s}$ \\
\hline $10^{\prime} \beta$ & & & & $1.51 \mathrm{~m}$ & & \\
\hline
\end{tabular}

*Assignments for positions with identical superscripts are interchangeable. 